\title{
Exploring Consumer Intention and Perceptions towards Purchasing Local Milk Powder
}

\author{
A.G.K. Wijesinghe*, U.M.R.M.I. Senadeera and N.R. Abeynayake
}

\begin{abstract}
Disputable information recently released through the mass media related to the imported milk powder has made a negative influence on powdered milk consumption in Sri Lanka. Conversely, this disputable information has been able to make high demand for local milk powder products. Therefore, this study was mainly focused to evaluate how the attitude towards the product, perceived knowledge, trust, price, availability, health consciousness, and subjective norms influence the local milk powder purchase intention of consumers. Primary data were collected through a questionnaire-based survey employing a face-to-face interview from a sample of 250 respondents covering five Divisional Secretariats in the Kegalle District. Data were analyzed by using Confirmatory Factor Analysis through Analysis of Moment Structure (AMOS).

Faculty of Agriculture and Plantation Management, Wayamba University of Sri Lanka, Makandura, Gonawilla (NWP), Sri Lanka.

*kusum_wijesinghe06@yahoo.com

https://orcid.org/0000-0002-0431-9823
\end{abstract}

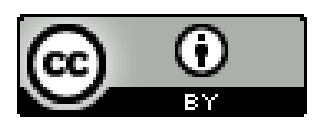

This article is published under the terms of the Creative Commons Attribution 4.0 International License which permits unrestricted use, distribution and reproduction in any medium provided the original author and source are credited.
The results revealed that trust, health consciousness, availability and price are the main factors that influence the local milk powder purchase intention of the consumers. The results also show that the lack of availability is the major issue in the local milk powder industry. Hence, the findings of the case of Kegalle District, are important to policymakers, producers, vendors, and the government to implement better strategies for the development of the local milk powder industry in Sri Lanka.

Keywords: Consumer, Factors influencing local milk powder, Purchase intention

\section{INTRODUCTION}

Milk is a rich source of several nutrients which are essential for the maintenance of good health. It plays a valuable role especially in infant feeding and alleviating nutritional deficiencies in all other age groups. According to the average monthly household expenditure for all food items, the expenditure for powdered milk takes a high percentage. Sri Lanka is not selfsufficient in milk production, thus, heavily depends on imported milk powder from countries like Australia and New Zealand. Hundred thousand 
metric tons of powdered milk have been imported to compensate for the consumption requirement in the country (Anon 2020; Lanka Business Online, 2020).

Local dairy producers in Sri Lanka only provide $40 \%$ of the required amount of powdered milk (Economic and Social Statics of Sri Lanka, 2018). Nevertheless, there are issues relating to the quality and food safety of imported milk powder products in recent years due to the presence of harmful additives in milk products (Boniface and Umberger, 2012; Casewell, 1998). According to the literature, such harmful additives in milk products are identified as arsenic, melamine, dicyandiamide (DCD) and animal fat (Perera et al., 2019; Azad and Ahmed, 2016; Anon, 2013). Sri Lankan consumers consider the quality attributes more when they purchase milk powder than that they purchase other dairy products (Saheeka et al., 2013). However, those issues of imported milk powder have been able to make changes in consumer attitudes. According to Anuranga (2012), several imported milk powder brands were tested in Sri Lanka and four of them were found to be contaminated with dicyandiamide (DCD). Due to the disputable issues of imported powdered milk during the last several years, consumer preference has been changed towards the local milk powder products in Sri Lanka (Economic and Social Statics of Sri Lanka, 2018).

According to the literature, several factors influence on purchase intention of powdered milk in Sri Lanka. Purchase intention is viewed as the motivation of a person to attempt to buy a product of a particular brand (Hoang et al., 2017). Researchers have mentioned that country image and brand image are supposed to have direct impacts on purchase intention (Anon, 2013; Cordell, 1993; Hoang et al., 2017; Tse and Gorn, 1993; Parkvithee and Miranda, 2012). Further, researchers have mentioned that consumer knowledge is also a factor that influences the purchase intention of a product (Alba and Hutchinson, 1987). In a recent study, it has been pointed out that consumers' product knowledge has a significant effect on the purchase intention of a product (Cakici and Shukla, 2017).

According to past studies, the subjective norm is another factor that influences on purchase intention of consumers for a product (Ortega et al., 
2014; Teng and Wang, 2015; Tonsor and Wolf, 2012). Subjective norm describes the degree of social pressure (i.e. from family, friends, news and magazines, and other significant sources) for a consumer to accept or avoid the purchasing of a product (Senadisai et al., 2014). Moreover, numerous studies have shown that price has a significant impact on the milk powder purchase intention of consumers (Senadisai et al., 2014; Kuma et al., 2012; Bingham et al., 2014).

The literature also highlighted that consumers' attitude towards a product is a function of consumers' evaluations of the attributes possessed with that product (Hysen et al., 2008; Howard, 1989; Fishbein and Ajzen, 1975). A better attitude towards a product makes more preference to buy that product (Lee and Lee, 2009; Ajzen and Fishbein, 1980).

Trust towards a product is another important factor in purchase intention. When consumers trust a product, it reduces uncertainty and enhances purchase intention (Hart and Saunders, 1997). Another research has mentioned that consumers evaluate the quality of a milk product and assure trust prior to purchase (Lakmali and
Abeynayake, 2016). Another most important factor for purchase intention is the knowledge of a product. Consumer knowledge is considered as a kind of product-related experience that influences purchase intention (Alba and Hutchinson, 1987). In a recent study, Cakici and Shukla (2017), has pointed out that consumers' product knowledge has a significant effect on purchase intention.

Product availability influences the purchase intention for a given product. Kumar and Babu (2014) have mentioned that availability is a major factor that affects the purchase intention of dairy products.

Some studies have been carried out in Sri Lanka to evaluate the purchasing behaviour of locally produced milk products. But there is no sufficient research carried out to investigate the factors that influence on purchase intention of locally produced powdered milk in Sri Lanka especially after the controversial issues that were recently happened about imported powdered milk. Hence, the objectives of this study were to examine how attitude, perceived knowledge, trust, health consciousness, subjective norms, availability and price determine the 
local milk powder purchase intention among consumers in Sri Lanka.

\section{MATERIALS AND METHODS}

\section{Conceptual Framework}

Based on the literature, the conceptual framework was proposed and it is illustrated in Figure 1 explaining the selected variables. Accordingly, the following hypotheses were depicted for this research.

H1: Attitude towards the product influences local milk powder purchase intention.
H2: Trust influences local milk powder purchase intention.

H3: Perceived knowledge influences local milk powder purchase intention. H4: Subjective norms influence local milk powder purchase intention.

H5: Product availability influences local milk powder purchase intention.

H6: Price of the product influences local milk powder purchase intention.

H7: Health consciousness influences local milk powder purchase intention.

\section{Data Collection}

Data were collected from 250 people who consume local milk powder by using a structured questionnaire.

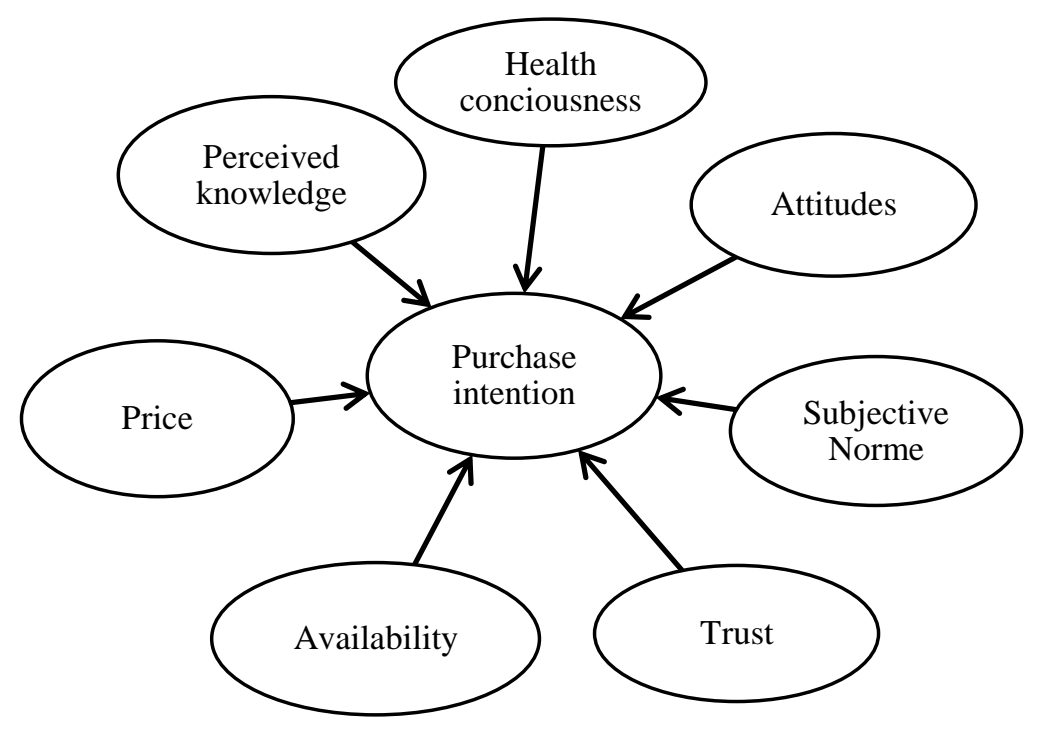

Figure 1. Proposed Conceptual Framework 
The questionnaire was pretested prior to the survey with a sample of potential consumers $(\mathrm{n}=20)$ and accordingly, minor modifications were done. Respondents were selected by using a multi-stage sampling method in Kegalle District. The multistage sampling process that included Divisional Secretariate (DS) divisions of the district is demonstrated in Figure 2.

\section{Measures}

The questionnaire consisted of nine constructs (i.e. factors) including personal information of the consumers, attitude towards the product, perceived knowledge, subjective norms, availability, price, health consciousness, trust, and purchase intention of local milk powder products. Thirty-one items were used to assess seven constructs other than personal information and purchase intention. All items were assessed using a five-point Likert-type scale, ranging from 1 to 5, where 1 denoted "strongly disagree" and 5 denoted "strongly agree". A summary of all items under each construct is given in Table 1.

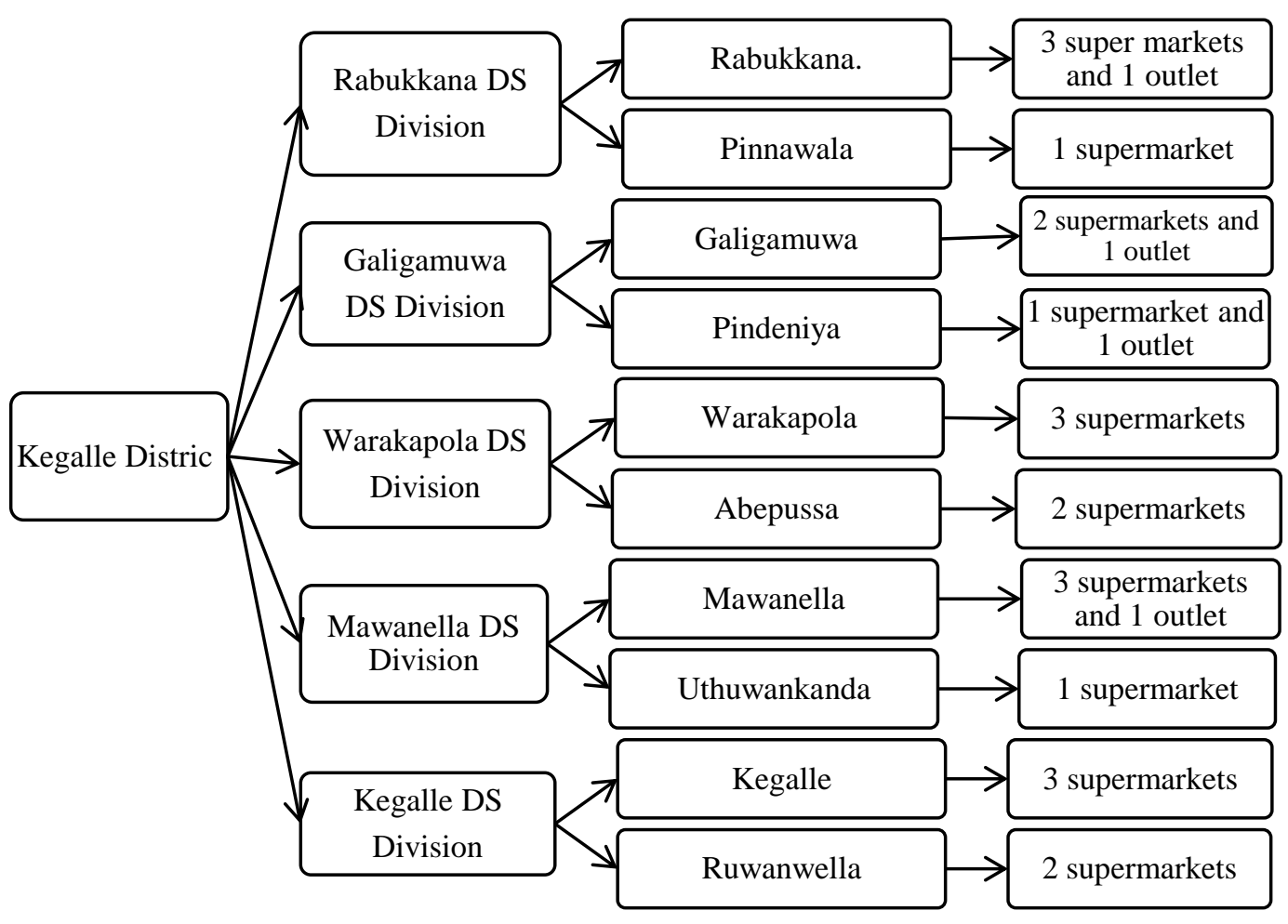

Figure 2. Multistage Sampling Procedure 
Table 1. Likert scale items used to measure the purchase intention

\begin{tabular}{|c|c|c|}
\hline Construct & Item Name & Likert Scale Items \\
\hline \multirow[t]{8}{*}{ Attitude towards the product } & PA1 & Good taste of local milk powder \\
\hline & PA2 & Attractive package design of the local milk powder products \\
\hline & PA3 & Importance of SLS, ISO certification of the product \\
\hline & PA4 & Importance of HALAL certification of the product \\
\hline & PA5 & Importance of brand name of the milk powder \\
\hline & PA6 & Good dissolving ability of the product \\
\hline & PA7 & Attractive advertisement of the product \\
\hline & PA8 & Good smell of the product \\
\hline \multirow[t]{3}{*}{ Subjective norms } & SN1 & Family perception on buying behaviour of the product \\
\hline & SN2 & Professionals' perception on buying behaviour of the product \\
\hline & SN3 & Influences of new research findings on buying behaviour of the product \\
\hline \multirow[t]{4}{*}{ Perceived knowledge } & K1 & Having knowledge on the problems of imported powdered milk \\
\hline & K2 & Having knowledge on the ingredients of local powdered milk. \\
\hline & $\mathrm{K} 3$ & Having knowledge on harmful ingredients which can be included in imported \\
\hline & K4 & Having knowledge on the absence of any harmful ingredients in local milk \\
\hline \multirow[t]{5}{*}{ Health consciousness } & H1 & I believe that local milk powder contains only natural ingredients. \\
\hline & $\mathrm{H} 2$ & I believe that local milk powder does not contain animal fat. \\
\hline & $\mathrm{H} 3$ & I believe that local milk powder does not create any health problems \\
\hline & $\mathrm{H} 4$ & I believe that local milk powder does not contain DCD \\
\hline & H5 & I believe that local milk powder does not contain melamine \\
\hline
\end{tabular}




\begin{tabular}{lll}
\hline Price & P1 & The low price of local milk powder products has a significant influence on my \\
& P2 & Even though the price is higher for local milk powder products, I buy them \\
& P3 & Price offers good value for local milk powder products \\
\hline Trust & T1 & I believe that the source of the collection of raw milk is \\
& T2 & I believe that the delivery process of raw milk is safe \\
& T3 & I believe that local milk powder product processing is safe \\
\hline Availability & AV1 & Poor availability of local brands creates a barrier to purchase. \\
& AV2 & Seek to purchase local milk powder products anyhow. \\
& AV3 & If local milk powder is not available, I buy local branded liquid milk. \\
AV4 & If local milk powder is not available, I buy local fresh milk \\
AV5 & If local milk powder is not available, I do not use milk. \\
\hline
\end{tabular}




\section{Data Analysis}

The Kaiser-Meyer-Olkin (KMO) test was applied to check the sampling adequacy for the multivariate analysis while Pearson Correlation Coefficient was employed to ensure that the multivariate analysis was not distorted (Rohlf, 2009).

The internal consistency of each construct was examined by using Cronbach's Alpha Reliability Coefficient. Descriptive statistics were used to analyse the demographic factors of the sample.

In this study, Confirmatory Factor Analysis (CFA) was used to examine the proposed model by using Analysis of Moment Structure (AMOS) in the SPSS 24 version. Byrne (2016) has elaborated that the CFA was done to determine whether all observed variables (Indicator variables) properly reflect their underlying constructs (Latent variables) and whether the measurement model has an acceptable fit to the data.

\section{RESULTS AND DISCUSSION}

\section{Descriptive Statistics of the Sample}

The majority of the respondents were women (54\%) and $46 \%$ were men in the studied sample. The sample contained $43 \%$ and $37 \%$ in the age groups of $16-$ 30 and 31-50, respectively. Among the respondents studied, $8 \%$ had primary education while others had above that level. The majority of the sample was in the secondary level of education $(61.2 \%)$. In the survey sample, 59.2\% were employed and $32.8 \%$ were among the income level between LKR 35,00160,000 (Table 2).

\section{Consumer Buying Behaviour}

The result revealed that $48.4 \%$ of respondents purchase only local milk powder while the majority of people consume both imported and local milk powder $(51.6 \%)$ as there is a shortage of local milk powder in the market.

\section{Consumer Brand Preference}

Consumers mainly focus on two popular local milk brands in the market. In the study sample, $41.6 \%$ of the respondents are brand loyal while 
the majority of the respondents $(58.4 \%)$ do not consider the brand name when purchasing local milk powder in the market.

\section{Sampling Adequacy}

Kaiser-Meyer-Olkin (KMO) and Bartlett's Test of sphericity (BTS) were conducted to verify the factorability of data. The recommended threshold value for $\mathrm{KMO}$ is at least 0.60 and BTS must be significant at $P<0.1$. The results for both of the tests were found to meet the minimum requirements (Table 3).

Table 2. Socio-demographic characteristics of the sample

\begin{tabular}{llc}
\hline \multicolumn{1}{c}{ Parameter } & \multicolumn{1}{c}{ Category } & Percentage (\%) \\
\hline Gender & Male & 46.0 \\
Age & Female & 54.0 \\
& 16-30 years & 43.0 \\
& 31-50 years & 37.0 \\
Employment Status & 50 years above & 20.0 \\
Monthly Income & Unemployed & 40.8 \\
& Employed & 59.2 \\
& Less than 15,000 (LKR) & 11.2 \\
& 15,001-35,000 (LKR) & 26.4 \\
Educational Level & 35,001- 60,000 (LKR) & 32.8 \\
& Above 60,000 (LKR) & 29.6 \\
& Primary & 8.0 \\
& Secondary & 61.2 \\
& Tertiary & 30.8 \\
& Sinhala & 92.0 \\
& Tamil & 6.8 \\
& Muslim & 1.2 \\
\hline
\end{tabular}




\section{Consistency of Constructs}

The Cronbach's Alpha coefficient is a useful indicator to test the internal consistency of the items that make up a construct. When Cronbach's Alpha is

Table 3. KMO and Bartlett's Test

\begin{tabular}{ll}
\hline $\begin{array}{l}\text { Sample adequacy } \\
\text { indicator }\end{array}$ & $\begin{array}{l}\text { Relevant } \\
\text { value for } \\
\text { indicator }\end{array}$ \\
\hline Kaiser-Meyer-Olkin & 0.709 \\
Measure of Sampling & \\
Adequacy & \\
Bartlett's Test of Sphericity & 6571.394 \\
Approx. Chi-Square & \\
df & 595 \\
Significant Probability & 0.000 \\
\hline
\end{tabular}

higher the reliability of the scale is higher (Dunn et al., 1994). Malhotra and Birks (2003) state that if the coefficient is above 0.65 it could be acceptable. Furthermore, the deletion of one or more items from a construct can also contribute to an increase of the Cronbach's Alpha Coefficient. All 31 items (statements) under the selected seven constructs, were checked separately for consistency using Cronbach's Alpha. Production Attitude (PA) showed 0.691 as Cronbach's Alpha after deleting items (PA4 and PA8). Similarly, item 3 from Subjective Norm, (SN3), and item 5 from
Availability, (AV5) were removed to bring the Cronbach's Alpha 0.762 and 0.788 respectively. Cronbach's Alpha for other 4 constructs: Trusts (T), Health Conscious $(\mathrm{H})$, Price $(\mathrm{P})$, and Perceived Knowledge (K), are 0.721, $0.870,0.740$, and 0.742 , respectively.

\section{Confirmatory Factor Analysis (CFA)}

CFA was used to validate the proposed model that assessed the overall quality of the measurement model. The maximum likelihood method was used to estimate the model and model fit was assessed by using Multiple Fit Indices (Table 4).

Table 4. Measurement model fit indices

\begin{tabular}{lc}
\hline \multicolumn{1}{c}{ Index } & $\begin{array}{c}\text { Measurement } \\
\text { Model Estimate }\end{array}$ \\
\hline Chi-square $\left(\chi^{2}\right)$ & 212.002 \\
df & 121 \\
Probability & 0.000 \\
Level & \\
$\chi^{2} /$ df Ratio & 1.887 \\
CFI & 0.901 \\
GFI & 0.944 \\
AGFI & 0.889 \\
RMSEA & 0.037 \\
\hline
\end{tabular}

Chi-square value (212.002) for the model was statistically significant $(\chi 2 / \mathrm{df}=1.887)$ with a root mean of squared error of approximation $($ RMSEA $)=0.037$, goodness-of-fit $(\mathrm{GFI})$ $=0.944$, adjusted goodness-of-fit (AGFI) 
$=0.889$, and comparative fit index (CFI) $=0.901$. According to Hair et al. (1998), the fit indices indicate a good model fit.

Table 5, shows that all standardized estimates are statistically significant except item K2 (indicator variable). Thus, the selected items effectively reflect each latent variable except the $\mathrm{K} 2$ variable. Item K2 indicates the 'knowledge of the ingredients included in local milk powder' and it does not contribute to the underlying construct of perceived knowledge.

Item PA1 shows the highest factor loading (0.974) for the attitude towards the product, indicating that the taste of local milk powder highly reflects the underlying construct of product attitude. Item SN1 shows higher factor loading (0.743) towards the subjective norm which indicates the higher family influence than the professional influence on purchase intention. Item T3 shows the highest factor loading (0.902) towards trust which indicates the safety of the milk production process. Item $\mathrm{H} 3$ shows the highest factor loading (0.967) towards health consciousness which indicates that no health risk is associated with consumption of local milk powder. Item P1 indicates the highest factor loading (0.553) towards the purchase intention, indicating that the low price of local milk powder influences the purchase intention.

The item AV1 shows the highest factor loading (1.032) towards the construct, availability, which is the poor availability of local milk powder as a barrier for purchasing. Figure 4, elaborates the structural relationship between selected constructs and purchase intention of local milk powder. Standardized Regression Weights obtained from Structural Equation Model between latent factors (constructs) and indicators (items), as well as the latent subfactor items and purchase intention are pointed out on arrows. The Figure clearly shows that the comparable importance of each item on the relevant construct and its association with the purchase intention of local milk powder.

Further, significant influences of all the constructs on purchasing intention are interpreted based on the probability values obtained from the output of Structural Equation Model analysis as indicated in Table 6 . According to Table 6, trust, availability and health consciousness significantly and positively enhance consumers' local milk powder purchase intention. Under the trust, four items were included which asked about 'safeness of local milk powder process', 'safeness of raw milk transportation process', 
Table 5. Confirmatory factor analysis (CFA) output

\begin{tabular}{|c|c|c|c|c|}
\hline Construct & $\begin{array}{l}\text { Estimate of } \\
\text { items }\end{array}$ & Cronbach's $\alpha$ & $\begin{array}{l}\text { Composite } \\
\text { Reliability }\end{array}$ & AVE \\
\hline Product Attitude & & 0.691 & 0.799 & \\
\hline PA1 & $0.974^{* * *}$ & & & .395 \\
\hline PA2 & $0.194^{* * *}$ & & & .321 \\
\hline PA3 & $0.229^{* *}$ & & & .441 \\
\hline PA5 & $0.888^{* *}$ & & & .390 \\
\hline PA6 & $0.631^{* *}$ & & & .269 \\
\hline PA7 & $0.274^{* * *}$ & & & .188 \\
\hline Subjective Norm & & 0.762 & 0.774 & \\
\hline SN1 & $0.743^{* *}$ & & & .713 \\
\hline SN2 & $0.531^{* *}$ & & & .850 \\
\hline Trust & & 0.721 & 0.754 & \\
\hline $\mathrm{T} 1$ & $0.833^{* * *}$ & & & .916 \\
\hline $\mathrm{T} 2$ & $0.878^{* * *}$ & & & .366 \\
\hline T3 & $0.902^{* * *}$ & & & .421 \\
\hline $\mathrm{T} 4$ & $0.681^{* * *}$ & & & .370 \\
\hline Health Consciousness & & 0.870 & 0.758 & \\
\hline H1 & $0.574^{* * *}$ & & & .441 \\
\hline $\mathrm{H} 2$ & $0.743^{* * *}$ & & & .572 \\
\hline H3 & $0.967^{* * *}$ & & & .668 \\
\hline $\mathrm{H} 4$ & $0.949^{* * *}$ & & & .804 \\
\hline H5 & $0.266^{* * *}$ & & & .779 \\
\hline Price & & 0.740 & 0.770 & \\
\hline P1 & $0.553^{* * *}$ & & & .824 \\
\hline P2 & $0.429^{* * *}$ & & & .717 \\
\hline P3 & $0.421^{* * *}$ & & & .831 \\
\hline Perceived Knowledge & & 0.742 & 0.765 & \\
\hline $\mathrm{K} 1$ & $0.806^{* * *}$ & & & .910 \\
\hline $\mathrm{K} 2$ & 0.884 & & & .761 \\
\hline K3 & $0.799^{* *}$ & & & .754 \\
\hline K4 & $1.082^{* * *}$ & & & .774 \\
\hline Availability & & 0.788 & 0.778 & \\
\hline AV1 & $1.032^{* * *}$ & & & .627 \\
\hline AV2 & $0.362^{* * *}$ & & & .590 \\
\hline AV3 & $0.385^{* * *}$ & & & .583 \\
\hline AV4 & $0.782^{* * *}$ & & & .718 \\
\hline
\end{tabular}

** Significant at $P<0.01,{ }^{* * *}$ Significant at $P<0.001, A V E=$ Average variance extracted 


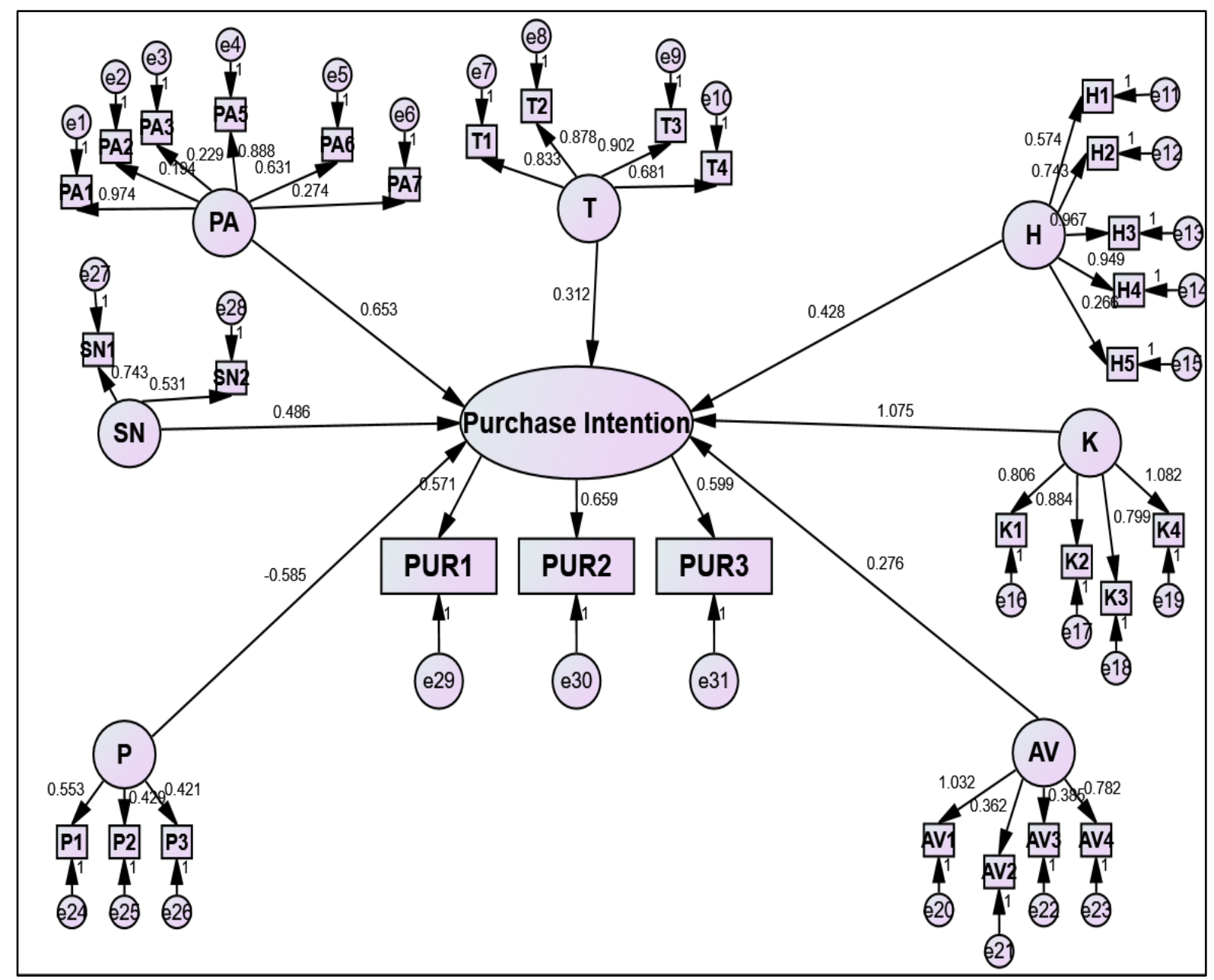

Figure 4. The structural relationship between constructs and the purchase intention

Table 6. Standardized regression weights (SRW) for the structural paths

\begin{tabular}{|c|c|c|}
\hline \multicolumn{2}{|c|}{ Hypothesized Relationships between Constructs and } & \multirow{2}{*}{$\begin{array}{c}\text { Estimates } \\
0.653\end{array}$} \\
\hline Purchase intention & $\leftarrow$ Attitude towards the product & \\
\hline Purchase intention & $\leftarrow$ Trust & $0.312^{* * *}$ \\
\hline Purchase intention & $\leftarrow$ Availability & $0.276^{* *}$ \\
\hline Purchase intention & $\leftarrow$ Perceived knowledge & 1.075 \\
\hline Purchase intention & $\leftarrow$ Price & $-0.585^{* *}$ \\
\hline Purchase intention & $\leftarrow$ Subjective norm & 0.486 \\
\hline Purchase intention & $\leftarrow$ Health consciousness & $0.428^{* * *}$ \\
\hline
\end{tabular}

*** Significant at $P<0.001, * *$ Significant at $P<0.05$ 
'safeness of local milk powder packaging' and 'safeness of raw milk collection process'. The results indicate that trust in local milk powder is one of the constructs that highly influence local milk powder purchase intention (SRW 0.312, $P<0.001$ ). Based on that, hypothesis two $(\mathrm{H} 2)$ constructed in this study can be proved. Therefore, we can propose that the local milk powder market can be improved by incorporating quality developments included under the construct of trust.

The results of the construct availability indicate that the availability of local milk powder highly influences local milk powder purchase intention (SRW 0.276, $P<0.05$ ), indicating the possibility of approving hypothesis five (H5).

Health consciousness was measured about the perceptions on harmful chemical residues (dicyandiamide, melamine, harmful animal fats), health problems that can be occurred due to the consumption of local milk powder and healthiness of ingredients in the local milk powder. Health consciousness is also a highly significant factor that influences local milk powder purchase intention (SRW 0.428, $P<0.001)$. Based on that, hypothesis seven (H7) constructed in this study can be proved. According to these findings, it can be proposed that if local milk powder producers adapt to the healthy practices and standard ingredients for the production process, the local milk powder market can be promoted.

The price of the milk powder significantly and negatively enhances the purchase intention of local powdered milk (SRW -0.585, P < 0.05), indicating that hypothesis six (H6) constructed in this study could be proved.

Attitude towards the product, perceived knowledge and subjective norms do not significantly affect local milk powder purchase intention. Hence, H1, H3 and H4 hypotheses are not supported by the results. This revealed that Sri Lankan consumers tend to buy local milk powder based on the trust in the local milk powder, availability of the local milk powder, price of the local milk powder and health consciousness on local milk powder. 


\section{CONCLUSION}

The findings of this study reveal that trust, availability and health consciousness factors (constructs) positively and significantly influence on purchase intention of local milk powder.

Trust was measured by four items which were asked about the 'safeness of local powder milk production process', 'safeness of raw milk transportation process', 'safeness of local milk powder packaging' and 'safeness of raw milk collection process'. Out of these four items, the most contributing items were the 'belief in the safe production process of local milk powder' and 'belief in the safe delivery process of raw milk'.

Availability was measured by five items and out of those items, the most influencing items were 'creating a barrier for purchasing local milk powder due to poor availability of local brands' and 'intention of buying local fresh milk in case unavailability of the local milk powder'.

Health consciousness was measured by using five items and out of them, the most contributing items for health consciousness were 'not creating any health problem by local milk powder' and 'not containing DCD (dicyandiamide) in local milk powder'.

These findings would be useful to provide recommendations at the policy level and industry level. According to this study, consumers purchase local milk powder mainly based on trust, availability and health consciousness. Therefore, the implementation of the safety measures in the raw milk delivery process and milk powder production process is important to enhance local milk powder purchase intention. Further, in order to increase the availability of local milk powder, the government should develop strategies, especially by encouraging farmers and giving infrastructure facilities for delivering process, etc. to meet the demand. Consumers believe that local milk powder does not contain harmful chemicals i.e. dicyandiamide, melamine and animal fat and local milk powder contains only natural ingredients. Therefore, marketing would not be an issue, if production could be increased with the help of government and private sector organizations. 


\section{REFERENCES}

Ajzen, I. and Fishbein, M. (1980). Understanding attitudes and predicting social behaviour. Englewood Cliffs, Prentice Hall.

Alba, J. and Hutchinson, J. W. (1987). Dimensions of consumer expertise. Journal of Consumer Research, 13(4): 1425.

Anon, (2013). China asks importers to recall contaminated Fonterra products. Bloomberg.

http://www.bloomberg. com/news/articles/2013-08-03/

(Accessed on 24. 07. 2019).

Anon, (2020). Government to implement price formula on imported milk. Daily Mirror. http://www.dailymirror.lk/business -news/Government-to-implementprice-formula-on-importedmilk/273-163926 (Accessed on 11.05.2020).

Anuranga, D. (2012). DCD, A potential shield to uplift local milk: Case study based on Sri Lankan milk powder industry. Scientific Research Journal, 2: 20-25.

Azad, T. and Ahmed, S. (2016). Common milk adulteration and their detection techniques. International Journal of Food Contamination, 3(22). DOI: org/10.1186/s40550-016-0045-3

Bingham, D., Dharmasena, S., Capps, O. and Salin, V. (2014). Demographic and economic factors affecting demand for brand-level milk in Texas. Agecon. http://ageconsearch.umn.edu/bitstr eam/162369/2/Bingham_Dharmase na_Capps_Salin_SAEA

_Dallas_TX_2014 (Accessed on 16.07.2019).

Boniface, B. and Umberger, W. (2012). Factors influencing Malaysian consumers' consumption of dairy products. $56^{\text {th }}$ Australian Agricultural Resource Economics Society (AARES) annual

conference. http://ageconsearch.umn.edu/recor d/124243/files/2012AC\%20Boniface \%20CP.pdf

Byrne, B.M. (2016). Structural Equation Modelling with Amos: Basic Concepts, Applications, and Programming ( $3^{\text {rd }}$ ed.). Routledge, New York. 3-16.

Cakici, N. M. and Shukla, P. (2017). Country-of-origin misclassification awareness and consumers' behavioural intentions: Moderating roles of consumer affinity, animosity and product knowledge. International Marketing Review, 34(3): 354-376.

Casewell, J. A. (1998). Valuing the benefits and costs of improved food safety and nutrition. Australian Journal of Agriculture and Resource Economics, 42: 409-474.

Cordell, V.V. (1993). Interaction effects of country of origin with branding, price and perceived performance risk. Journal of International Consumer Marketing, 5(2): 5-20.

Dunn, S. C., Seaker, R. F. and Waller, M. A. (1994). Latent variables in 
business logistics research: scale development and validation. Journal of Business Logistics, 15(2): 145.

Economic and Social Statistics of Sri Lanka, (2018). Central Bank of Sri Lanka.

Fishbein, M. and Ajzen, I. (1975). Belief, Attitude, Intention and Behaviour: An Introduction to Theory and Research. Addison-Wesley, Reading, MA.

Hart, P. and Saunders, C. (1997). Power and trust: critical factors in the adoption and use of electronic data interchange. Organization Science, 8: 23-42.

Hoang, T. P. M. Le., Nguyen, P. V., Dinh, H. P. and Dang, C. N. (2017). Effects of country of origin and product features on customer purchase intention: a study of imported powder milk. Academy of Marketing Studies Journal, 21(1): 1140-1167.

Howard, J.A. (1989). Consumer behaviour in marketing strategy. Prentice-Hall, Englewood Cliffs.

Hysen, B., Mensur, V., Muje, G., Hajrip, M., Halim, G., Iliriana, M. and Njazi, B. (2008). Analysis of consumer behaviour in regard to dairy products in Kosovar. Journal of Agricultural Science, 46(3): 281-290.

Kuma, B., Baker, D., Getnet, K. and Kassa, B. (2012). Factors affecting packed and unpacked fluid milk consumption in Wolaita Zone of SNNP Regional State, Ethiopia. Journal of Applied Science Technology, 3(1): 23-31.
Kumar, A. and Babu, S. (2014). Factors influencing consumer buying behaviour with special reference to dairy products in Pondicherry state. International Monthly Refereed Journal of Research in Management Technology, 3: 65-73.

Lakmali, W. M. T. C. and Abeynayake N. R. (2016). Dynamics of consumer behaviour and consumer perception on fresh milk consumption: Case in Kandy district Sri Lanka. Proceedings of $16^{\text {th }}$ Agricultural Research Symposium, Wayamba University of Sri Lanka, pp. 6-10.

Lanka Business Online (2020). Pelwatte explore continued local diary selfsufficiency post-COVID-19. Lanka business.

https://www.lankabusinessonline.c om/pelwatte-to-explore-continued localndairy-self-sufficiency-postcovid-19/, (Accessed on 02.05.2021).

Lee, J.K. and Lee, W.N. (2009). Countryof-origin effects on consumer product evaluation and purchase intention: the role of objective versus subjective knowledge. Journal of International Consumer Marketing, 21(2): 137-151.

Malhotra, N. K. and Birks, D. F. (2003). Marketing research: An applied approach $\left(2^{\text {nd }} E d\right.$.). Prentice Hall.

Ortega, D.L., Wang, H.H. and Widmar, N.J.O. (2014). Effect of media headlines on consumer preference for food safety, quality and environmental attributes. Australian 
Journal and Resource Economics, 58: 293-300.

Parkvithee, N. and Miranda, M. J. (2012). The interaction effect of country-of-origin, brand equity and purchase involvement on consumer purchase intentions of clothing labels. Asia Pacific Journal of Marketing and Logistics, 24(1): 7-22.

Perera, P., Munasinghe, H., and Marapana, R.A.U.J. (2019). Quality assessment of selected dairy products in Sri Lankan market. Journal of Food Quality. DOI: org/10.1155/2019/6972427.

Rohlf, F. J. (2009). NTSYSpc Numerical taxonomy and multivariate analysis system, v. 2.2. Setauket, New York: Exeter Software.

Saheeka, R.F., Udugama, J.M.M., Jayasinghe-Mudalige, U.K. and Attanayake, A.M.C.M. (2013). Determinants of dairy product consumption patterns: The role of consumer perception on food quality attribute. Proceedings of $12^{\text {th }}$ Agricultural Research Symposium, Wayamba University of Sri Lanka. 419423.

Senadisai, P., Trimetsoontorn, J. and Fongsuwan, W. (2014). Model of factors influencing the intention to purchase lactose-free milk for the population of Bangkok. Research Journal of Business Management, 8(3): 284-293.

Teng, C. and Wang, Y. (2015). Decisional factors driving organic food consumption: Generation of consumer purchase intentions. British Food Journal, 117: 1066-1081.

Tonsor, G.T. and Wolf, C.A. (2012). Effect of video information on consumers: milk production attributes. American Journal of Agricultural Economics, 92: 503-507.

Tse, D.K. and Gorn, G.J. (1993). An experiment on the salience of country-of-origin in the era of global brands. Journal of International Marketing, 1(1): 57-76. 